\title{
CARDIAC CEPHALALGIA
}

\author{
I Made Oka Adnyana, Adriana Marsha Yolanda
}

\author{
Departemen Neurologi, FK Universitas Udayana/RSUP Sanglah, Denpasar, Bali, Indonesia
}

Diterima 17 Januari 2020

Disetujui 30 Maret 2020

Publikasi 15 Mei 2020

Korespondensi: okaadnyanadrsps@yahoo.com
Cara merujuk artikel ini: Adnyana (et al). 2020. Cardiac cephalalgia. Callosum Neurology Journal 3(1): 59-62. DOI: https://doi.org/10.29342/cnj.v3i2.108

\begin{abstract}
ABSTRAK
Cardiac cephalalgia merupakan nyeri kepala seperti migraine, umumnya diperberat dengan aktivitas fisik, timbul selama peristiwa myocardial ischaemia, membaik dengan pemberian nitroglycerine. Cardiac cephalalgia merupakan kasus nyeri kepala yang jarang namun dapat mempengaruhi aspek biopsikososial dan kualitas hidup penderita. Berdasarkan The Internasional Classification of Headache Disorder (ICHD), cardiac cephalalgia digolongkan ke dalam nyeri kepala sekunder yang terkait dengan kelainan homeostasis. Artikel ini membahas mengenai cardiac cephalalgia terkait definisi, epidemiologi, patofisiologi, gambaran klinis, penegakan diagnosis, diagnosis banding, serta pilihan terapinya
\end{abstract}

dengan melakukan pencarian, review dan telaah serta menyimpulkan berbagai literatur terbaru terkait hal tersebut. Cardiac cephalalgia sering ditemukan pada usia dekade lima. Penegakkan diagnosis berdasarkan nyeri kepala yang berkaiatan dengan adanya myocardial ischaemia, dan berespon baik dengan pemberian nitroglycerine. Penatalaksanaan cardiac cephalalgia menitikberatkan pada penanganan myocardial ischaemia. Nitroglycerine merupakan pilihan utama untuk nyeri kepala.

Kata Kunci: cardiac cephalalgia, nyeri kepala sekunder, iskemia myokard

\begin{abstract}
Cardiac cephalalgia is a headache that presents like migraine, generally exacerbated by physical activity, arising during the events of myocardial ischaemia and improves by administration of nitroglycerine. Cardiac cephalalgia is a rare case of headache but can affect biopsychosocial aspects and the quality of life of patients. According The International Classification of Headache Disorder (ICHD), cardiac cephalalgia is classified into secondary headaches associated with homeostatic abnormalities. This article discusses about cardiac cephalalgia in terms of definition, epidemiology, pathophysiology, clinical picture, diagnosis, differential
\end{abstract}

diagnosis, and therapeutic options by searching, reviewing and concluding various recent related literatures. Cardiac cephalalgia is often found at the fifth decade. The diagnosis is based on headaches related to the presence of myocardial ischaemia and responds well to nitroglycerine. Management of cardiac cephalalgia focuses on the management of myocardial ischaemia. Nitroglycerine is the best choice for cephalgic headaches treatment.

Keywords: cardiac cephalalgia, secondary headache, myocardial ischaemia 


\section{Latar Belakang}

Pengetahuan dan pembagian klasifikasi nyeri kepala telah berkembang dan mengalami perubahan dari masa kemasa. Nyeri kepala merupakan rasa nyeri atau tidak mengenakan pada daerah atas kepala memanjang dari orbita sampai kedaerah belakang kepala (area oksipital dan sebagian daerah tengkuk). ${ }^{1}$ Berdasarkan klasifikasi The International Classification of Headache Disorder (ICHD) edisi ketiga, nyeri kepala dibedakan menjadi nyeri kepala primer, nyeri kepala sekunder, dan neuralgia kranial, sentral atau nyeri fasial primer dan nyeri kepala lainnya. ${ }^{2}$

Cardiac cephalalgia adalah nyeri kepala seperti migraine, umumnya namun tidak selalu diperberat dengan aktivitas fisik, timbul selama peristiwa myocardial ischaemia, membaik dengan pemberian nitroglycerine. Cardiac cephalalgia merupakan bagian nyeri kepala sekunder yang terkait dengan kelainan homeostasis. Secara patofisiologi, terjadinya cardiac cephalalgia dapat dijelaskan dengan adanya nyeri alih, penurunan mendadak cardiac output, pelepasan mediator kimia terkait myocardial ischaemia dan vasospasme arteri serebral. ${ }^{2}$ Diagnosis cardiac cephalalgia dapat ditegakkan dengan anamnesis, pemeriksaan fisik dan pemeriksaan penunjang yang komprehensif. Terapi pada cardiac cephalalgia berfokus pada penanganan penyakit yang mendasarinya, yaitu pemberian nitroglycerine. Penegakkan diagnosis cardiac cephalalgia masih merupakan hal yang sulit. Klinisi harus mampu menyingkirkan penyebab lain yang dapat menimbulkan gejala serupa.

\section{Diskusi}

\section{Definisi dan Epidemiologi}

Istilah cardiac cephalalgia diperkenalkan pertama kali oleh Lipton tahun 1997. Saat itu ditemukan 2 pasien laki-laki yang mengalami nyeri kepala hebat, saat dilakukan pemeriksaan exercise electrocardiography. Hasil perekaman kardial menunjukkan adanya perubahan gelombang $\mathrm{S}$ dan T. Setelah itu, dilakukan pemeriksaan coronary angiogram, dan didapatkan adanya penyumbatan 3 pembuluh darah coroner. Gejala nyeri kepala membaik seiring dengan pengobatan sumbatan jantung coroner. ${ }^{3}$

Cardiac cephalalgia seringkali mengenai usia dekade ke-5, dengan faktor risiko penyakit kardiovaskular (usia, merokok, hiperlipidemia, hipertensi, diabetes mellitus, dan obesitas). Saat ini belum ada studi mengenai prevalensi cardiac cephalalgia, literature yang ada berdasarkan laporan kasus yang ditemukan. ${ }^{4}$

\section{Patofisiologi}

Mekanisme yang mendasari cardiac cephalalgia masih belum diketahui. ${ }^{5}$ Namun, berkembang beberapa hipotesis penyebab terjadinya cardiac cephalalgia.

Ada empat teori mengenai patogenesis cardiac cephalalgia. $^{3}$

1. Teori nyeri alih. Serabut saraf simpatis yang mempersarafi jantung berasal dari ganglia servikal dan thorakal. Ganglia ini juga mempersarafi struktur mata, wajah, leher dan serebrovaskular. ${ }^{5}$ Nyeri alih dari jalur ini menyebabkan nyeri kepala. Nyeri yang berasal dari miokardium dipersarafi oleh serabut saraf otonom, diteruskan ke batang otak, dimana di batang otak juga terdapat serabut saraf otonom lainnya yang berasal dari daerah kepala. ${ }^{6}$ Penurunan mendadak cardiac output yang diakibatkan iskemia pada jantung. Penurunan mendadak cardiac output mengakibatkan peningkatan resistensi ventrikel kiri dan atrium kanan. Hal ini menyebabkan penurunan aliran darah vena otak, sehingga terjadi peningkatan tekanan intrakranial. ${ }^{5}$

2. Pelepasan mediator yang menyebabkan vasodilatasi dari mikoardium yang mengalami iskemia dan adanya kongesti vena serebral yang diakibatkan gagal jantung. Pelepasan mediator kimia, seperti serotonin, bradikinin, histamin, substansi $P$ dan dengan agen vasodilator pada otak, yang diakibatkan adanya myocardial ischemia. Mediator ini berikatan pada struktur peka nyeri. Peningkatan tekanan intrakardiak yang berkaitan dengan angina, menyebabkan pelepasan atrial natriuretic peptide (ANP) dan brain natriuretic peptide (BNP), sebagai respon terhadap peningkatan atrium kanan dan ventrikel kiri. ANP dan BNP merupakan agen vasodilator dan menyebabkan nyeri kepala. $^{7}$

3. Cardiac cephalalgia diakibatkan adanya vasospasme arteri koroner bersamaan dengan arteri serebral. $^{5}$

4. Hipoperfusi menyebabkan vasokonstriksi pembuluh darah yang bersifat reversible. Saat terjadi iskemia miokardial, sistem saraf simpatis teraktivasi dan menyebabkan konstriksi arteri intrakranial. Hipoperfusi juga menyebabkan cortical spreading depression (CSD). Hal ini menyebabkan nyeri kepala dengan intensitas sedang-berat. ${ }^{4}$ 


\section{Gambaran Klinis dan Penegakan Diagnosis}

Pada cardiac cephalalgia, beberapa faktor yang mendukung diantaranya adalah usia, memiliki faktor risiko penyakit kardiovaskular, adanya keluhan nyeri dada, dan nyeri kepala dipicu oleh aktivitas. Manifestasi klinis cardiac cephalalgia bervariasi dari nyeri kepala dengan intensitas berat, tidak dapat dilokalisasi, dapat unilateral ataupun bilateral. Nyeri kapala dapat disertai dengan gejala lain seperti mual (30\%), nyeri pada lengan kiri yang menyebar ke rahang atau nyeri epigastrium (50\%). Nyeri kepala seringkali berkaitan dengan adanya aktivitas, baik aktivitas ringan seperti berjalan, maupun aktivitas berat. Nyeri kepala tidak harus disertai dengan olahraga. ${ }^{8}$ Umumnya tidak memiliki riwayat nyeri kepala sebelumnya. Nyeri kepala dapat mengenai $\geq 1$ area pada area frontal, temporal, parietal ataupun oksipital. Sifat nyeri kepala bervariasi. Sebagian besar nyeri kepala dicetuskan dengan aktivitas, berkurang dengan beristirahat atau konsumsi nitrogliserin. Nyeri kepala dapat menjadi satusatunya gejala yang dialami oleh pasien (27\%). ${ }^{7}$

Diagnosis cardiac cephalalgia diperkenalkan pertama kali pada tahun 1997. Cardiac cephalalgia termasuk dalam nyeri kepala sekunder yang berkaitan dengan kelainan homeostasis. Elektrokardiogram dapat ditemukan tanda myocardial ischaemia. Peningkatan enzim jantung berupa Myoglobin, Creatine kinase-MB (CK-MB), Troponin. Pemeriksaan coronary angiography dapat mendeteksi adanya stenosis pembuluh darah koroner. ${ }^{8}$

\section{Kriteria diagnosis: ${ }^{2}$}

A. Setiap nyeri kepala yang memenuhi kriteria C

B. Myocardial ischaemia akut telah terdiagnosis

C. Bukti sebab-akibat ditunjukkan oleh sedikitnya dua hal berikut

1. Nyeri kepala berkembang seiring dengan timbulnya myocardial ischaemia yang akut

2. Salah satu atau kedua berikut
a. Nyeri kepala secara signifikan memburuk bersamaan dengan memburuknya myocardial ischaemia
b. Nyeri kepala membaik secara signifikan atau sembuh bersamaan dengan perbaikan atau resolusi myocardial ischaemia

3. Nyeri kepala memiliki setidaknya dua dari empat karakteristik berikut
a. Intensitas sedang hingga berat

b. Disertai mual c. Tidak disertai dengan phototophia atau fonofobia

d. Diperburuk oleh aktivitas

4. Nyeri kepala disembuhkan oleh nitrogliserin atau derivat nya

D. Tidak memenuhi kriteria diagnosis ICHD-3 yang lain

\section{Diagnosis Banding}

Seringkali didiagosis dengan nyeri kepala primer, seperti migraine, migrainous thoracalgia, tension type headache ${ }^{7}$ Selain itu, dapat juga didiagnosis dengan nyeri kepala terkait nitric oxide (NO). ${ }^{9}$

Cardiac cephalalgia dibedakan dengan migraine Penatalaksanaan yang diberikan sangat berbeda, dimana penggunaan vasokonstriktor pada cardiac cephalalgia dapat menyebabkan perburukan iskemia miokard. Pada kasus ini diperlukan evaluasi klinis dengan mencari faktor risiko yang berkaitan dengan penyakit jantung dan pemeriksaan fungsi jantung dengan pemeriksaan elektrokardiogram. ${ }^{7}$

Migrainous thoracalgia, merupakan migraine yang diserta dengan aura, berupa nyeri dada dan parestesi lengan. Aura yang ditimbulkan menyerupai dengan keluhan penyakit jantung yang dapat ditemukan pada penderita. ${ }^{7}$

Migraine dengan Patent Foramen Ovale (PFO). Prevalensi PFO pada pasien migraine lebih tinggi dibandingkan populasi umum dan PFO lebih sering ditemukan pada pasien migraine dengan aura dibandingkan dengan migraine tanpa aura. Prevalensi migraine dengan aura lebih banyak pada PFO berukuran besar. ${ }^{11}$ Kondisi PFO yang dilakukan penutupan memberikan hasil perbaikan dari migraine. ${ }^{10}$

\section{Penatalaksanaan}

Hingga saat ini, rekomendasi terapi cardiac cephalalgia menitikberatkan pada penanganan myocardial infarction. Pengenalan cardiac cephalalgia penting dalam penatalaksanaan. Manifestasi klinis yang dikeluhkan menyerupai migren. Pemberian obat-obatan yang menyebabkan vasokonstriksi (triptan, ergotamine) tidak disarankan bila memiliki penyakit jantung iskemik. ${ }^{13}$ Keluhan nyeri kepala pada cardiac cephalalgia tidak berespons terhadap obat antiinfalamasi non steroid (OAINS). Penanganan cardiac cephalalgia dan iskemia jantung menggunakan obat-obatan vasodilator, namun dapat memicu nyeri kepala pada pasien dengan migraine. Cardiac cephalalgia berespon dengan 
pemberian nitrat. Nitrat bekerja dengan menyebabkan vasodilatasi arteri serebral, mencetuskan nyeri kepala pada orang normal dan nyeri kepala primer seperti migraine. Respon yang baik setelah penggunaan nitrat merupakan salah satu diagnosis cardiac cephalalgia. Hal ini juga dirasakan pada pasien yang selesai menjalani angioplasty atau operasi bypass, nyeri kepala membaik. Cardiac cephalalgia dapat terjadi kembali bila didapatkan stenosis ulang pada pembuluh darah koroner. ${ }^{7}$

\section{Simpulan}

Cardiac cephalalgia merupakan penyakit yang seringkali tidak terdiagnosis, tetapi berdampak signifikan terhadap kualitas hidup penderita.

\section{Daftar Rujukan}

1. Sjahrir H. Kelompok Studi Nyeri Kepala Perhimpunan Dokter Spesialis Saraf Indonesia (PERDOSSI). 2005;1-92.

2. Olesen J. Preface. Cephalalgia. 2018;38(1):5.

3. Lipton RB, Lowenkopf $T$, Bajwa ZH, Leckie RS, Ribeiro S, Newman LC, et al. Cardiac cephalgia: A treatable form of exertional headache. Neurology. 1997;49(3):813-6.

4. Wang $M$, Wang L, Liu C, Bian X, Dong Z, Yu S. Cardiac cephalalgia : one case with cortical hypoperfusion in headaches and literature review. J Headache Pain. 2017;18(1).

5. Shankar A, Allan CLM, Smyth D, Jardine D. Cardiac cephalgia: a diagnostic headache. Intern Med J. 2016;46(10):1219-21.

6. Elgharably $Y$, Iliescu C, Sdringola S, Yusuf SW. Headache : A Symptom of Acute Myocardial Infarction. Eur J Cardiovasc Med. 2013;11(111):170-5.

7. Sjahrir H. Kelompok Studi Nyeri Kepala Perhimpunan Dokter Spesialis Saraf Indonesia (PERDOSSI). 2005;1-92.

8. Olesen J. Preface. Cephalalgia. 2018;38(1):5.

9. Lipton RB, Lowenkopf $\mathrm{T}$, Bajwa ZH, Leckie RS, Ribeiro S, Newman LC, et al. Cardiac cephalgia: A treatable form of exertional headache. Neurology. 1997;49(3):813-6.

10. Wang M, Wang L, Liu C, Bian X, Dong Z, Yu S. Cardiac cephalalgia : one case with cortical hypoperfusion in headaches and literature review. J Headache Pain. 2017;18(1).
Meskipun ICHD-3 telah merumuskan kriteria diagnosis untuk kelainan ini, namun penegakan diagnosis yang akurat masih menjadi tantangan yang besar bagi klinisi. Penegakan diagnosis cardiac cephalalgia berdasarkan anamnesis, pemeriksaan fisik, dan pemeriksaan penunjang yang mendukung. Pemberian golongan nitrat efektif guna mengatasi nyeri kepala.

\section{Konflik Kepentingan}

Penulis tidak memiliki konflik kepentingan dalam publikasi artikel ini.

11. Shankar A, Allan CLM, Smyth D, Jardine D. Cardiac cephalgia: a diagnostic headache. Intern Med J. 2016;46(10):1219-21.

12. Elgharably $Y$, Iliescu C, Sdringola S, Yusuf SW. Headache : A Symptom of Acute Myocardial Infarction. Eur J Cardiovasc Med. 2013;11(111):170-5.

13. Torres-Yaghi Y, Salerian J, Dougherty C. Cardiac Cephalgia. Curr Pain Headache Rep. 2015;19:(4).

14. Queiroz LP. Unusual headache syndromes. Headache. 2013;53(1):12-22.

15. Bini A, Evangelista A, Castellini $P$, Lambru G, Ferrante T, Manzoni GC, et al. Cardiac cephalgia. J Headache Pain. 2009;10(1):39.

16. Lip PZY, Lip GYH. Patent foramen ovale and migraine attacks: A systematic review. Am J Med [Internet]. 2014;127(5):411-20. Available from: http://dx.doi.org/10.1016/j.amjmed.2013. 12.006 .

17. Marie-Germaine B. Patent Foramen Ovale and Migraine: Evidence for a Link? American Headache Society and Blackwell Publishing. 2006;3(2):44-51.

18. Providencia RA. Headache and Ccardiovascular disease: Old Symptoms, New Proposals. Future Cardiol. 2010;6:703-723.

19. Morlote JG, Garcia MF, Fernandez JT, Catedral ML, Rodriguez R, Pascual J. Cardiac Cephalgia : an Underdiagnosed Condition? 2005;58(12):1476-8. Rev Esp Cardiol. 2005;58(12):1476-1478. 